\title{
Analisis dan Perancangan Sistem Informasi Fasilitas Sekolah
}

\author{
Fergie Joanda Kaunang \\ Program Studi Sistem Informasi, Fakultas Ilmu Komputer, Universitas Klbat \\ E-mail: fergie@unklab.ac.id
}

\begin{abstract}
Abstrak
Sistem dapat didefinisikan sebagai elemen-elemen yang berkaitan satu sama lain untuk menjalankan satu tujuan yang sama. Selanjutnya, dalam mengembangkan sebuah sistem dibutuhkan keterlibatan empat komponen yakni masukan, pengolahan, keluaran, dan balikan atau control Perkembangan teknologi ini sangat bermanfaat dalam memecahkan permasalahanpermasalahan dalam berbagai bidang termasuk dalam bidang pendidikan tak terkecuali pada sekolah menengah pertama. Mulai dari tinjauan dan pengamatan langsung ke SMPN 2 Airmadidi. Peneliti berminat untuk melakukan perubahan terhadap sistem informasi yang dimiliki oleh sekolah dimana sistem ini belum terkomputerisasi. Pendekatan yang digunakan adalah pendekatan terstruktur yakni Data Flow Diagram (DFD).
\end{abstract}

Kata Kunci-Sistem Informasi, Analisa, Perancangan, Data Flow Diagram

\begin{abstract}
System can be defined as interconnected elements in order to complete a task. Moreover, there are four components that are need to be involved to develop a system. These four elements are input, process, output and control. With the development of technology nowadays, it gives significant benefits in problem solving fields including problems in educational fields in this case junior high school. Based on our observation and interview with the stakeholders of SMP Negeri 2 Airmadidi, we decided to design an information system that covers the school's facilities which are the library and the school's medication unit. The current system is not computerized. Therefore, using structured analysis which is the Data Flow Diagram this study aim to develop a system that can be implemented in the future.
\end{abstract}

Keywords—Information System, Analysis, Design, Data Flow Diagram.

\section{Pendahuluan}

Sistem dapat didefinisikan sebagai elemen-elemen yang berkaitan satu sama lain untuk menjalankan satu tujuan yang sama. Selanjutnya, dalam mengembangkan sebuah sistem dibutuhkan keterlibatan empat komponen yakni masukan, pengolahan, keluaran, dan balikan atau control [1]. Keempat komponen tersebut digabungkan ke dalam tahapan-tahapan pengembangan sistem (System Development Life Cycle). Siklus ini merupakan suatu pendekatan bertahap untuk menganalisa dan merancang suatu sistem yang lebih spesifik terhadap kegiatan pengguna [2]. Adapun tahapan umum dalam mengembangkan sistem mencakup tahap perencanaan sistem (system planning), analisis sistem (system design), implementasi sistem (system implementation), dan penggunaan sistem (system utilization) [2-4].

Perkembangan teknologi ini sangat bermanfaat dalam memecahkan permasalahanpermasalahan dalam berbagai bidang termasuk dalam bidang pendidikan tak terkecuali pada sekolah menengah pertama. Mulai dari tinjauan dan pengamatan langsung ke SMPN 2 Airmadidi. Peneliti berminat untuk melakukan perubahan terhadap sistem informasi yang 
dimiliki oleh sekolah dimana sistem ini belum terkomputerisasi. Dengan sistem informasi yang baru diharapkan dapat mempermudah dan membantu dalam penyimpanan data dan dalam penggunaan fasilitas sekolah yang ada, terutama fasilitas perpustakaan dan usaha kesehatan sekolah (UKS).

Setelah melakukan pengamatan dan wawancara, peneliti melihat kesempatan untuk merancang suatu sistem informasi untuk fasilitas sekolah seperti perpustakaan dan usaha kesehatan sekolah. Sistem yang akan dirancang berupa sistem yang sudah terkomputerisasi dan terintegrasi untuk meningkatkan pelayanan sekolah untuk para siswa, mengingat kedua fasilitas ini adalah fasilitas yang penting dalam mendukung kegiatan belajar mengajar dan ekstrakurikuler sekolah. Sistem ini akan terhubung, sehingga siswa dengan menggunakan user id saja dapat mengakses semua fasilitas tersebut tanpa harus memiliki kartu perpustakaan dan kartu kesehatan yang berbeda. Data siswa tersebut juga akan disimpan ke dalam database untuk mempermudah pencarian. Sistem sendiri akan dikendalikan oleh admin dan pengguna (staff atau guru dan siswa).

\section{ANALISA SISTEM}

Metode yang digunakan dalam merancang sistem informasi fasilitas sekolah ini adalah Data Flow Diagram (DFD). DFD sendiri juga dikenal dengan diagram alur kerja dimana metode ini adalah salah satu alat atau perangkat yang digunakan untuk mengembangkan sistem ataupun perangkat lunak yang terstruktur untuk menggambarkan sistem menjadi jaringan alur data yang menunjukan proses fungsional ataupun proses bisnis yang ada [5, 6]. Untuk menggambarkan alur dari proses sistem yang akan peneliti buat, peneliti menggambar data flow diagram hingga level 1.

\subsection{Context-level DFD}

Diagram ini merupakan level yang paling tinggi dari DFD yang mendeskripsikan asosiasi sistem dengan lingkungan eksternalnya. Diagram konteks dari penelitian ini digambarkan pada gambar 1 .

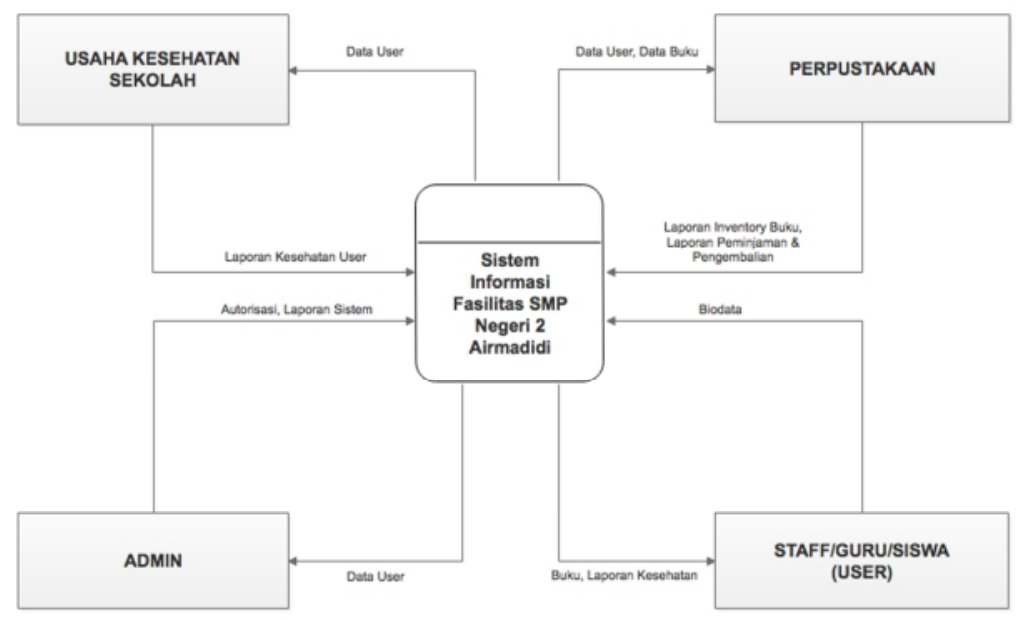

Gambar 1 Context Level DFD

Berdasarkan gambar 1 dapat dilihat nama dari sistem yang akan dikembangkan adalah sistem informasi fasilitas SMP Negeri 2 Airmadidi. Terdapat empat terminator atau entitas luar yang berkomunikasi dengan sistem yakni usaha kesehatan sekolah, perpustakaan, administrator, dan pengguna yang terdiri atas staff, guru, ataupun siswa. Selain keempat terminator tersebut 
juga terdapat alur data yang digambarkan dengan anak panah dari dan ke sistem untuk masingmasing terminator.

\subsection{DFD Level 0}

Diagram ini merupakan diagram dekomposisi dari Context Level DFD yang telah dipaparkan pada bagian sebelumnya. Adapun detil proses dan alur data dari DFD Level 0 diberikan pada gambar 2. Terdapat empat proses utama yang digambarkan oleh DFD Level 0 ini yakni proses daftar, pemeriksaan, pengembalian, dan peminjaman dengan masing-masing alur data dari dan ke masing-masing terminator atau entitas. Penomoran pada masing-masing proses pada diagram bertujuan untuk menguraikan proses yang lebih detil yang nantinya akan digambarkan pada DFD Level 1. Nomor tersebut tidak menunjukkan urutan proses.

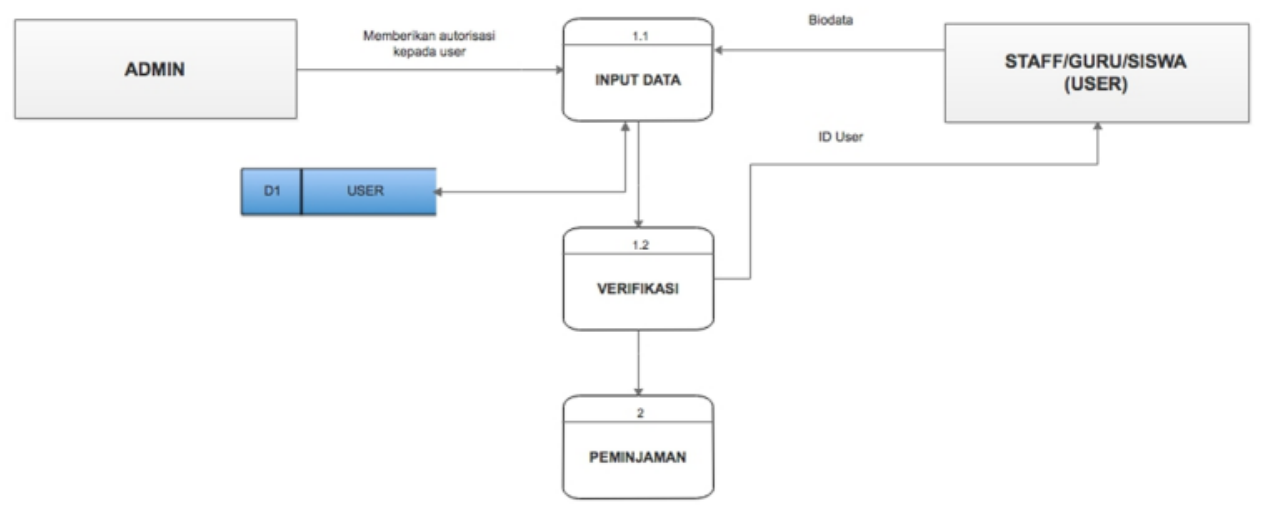

Gambar 2 DFD Level 0

\subsection{DFD Level 1}

Diagram ini adalah diagram yang diuraikan dari DFD Level 0 yang menggambarkan sub-proses dari setiap proses utama pada DFD Level O. Pada analisa sistem ini terdapat empat diagram masing-masing dari proses daftar, peminjaman, dan pengembalian.

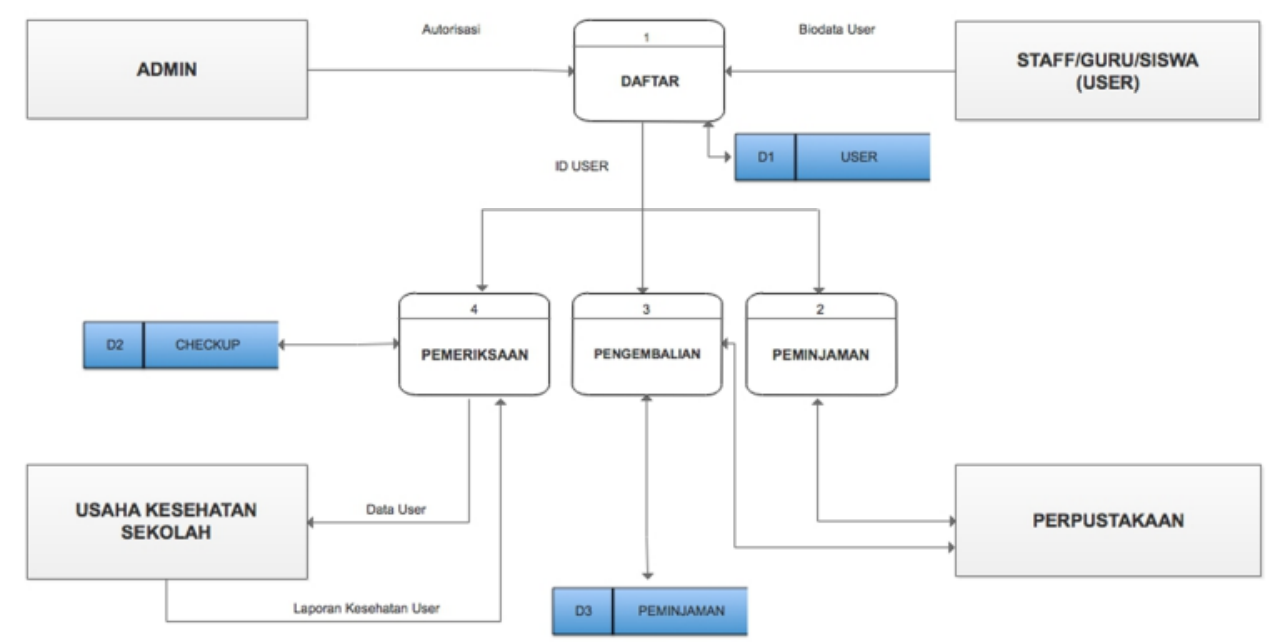

Gambar 3 DFD Level 1 untuk proses Daftar tersebut.

Gambar 3, 4, dan 5 adalah gambar dari DFD Level 1 untuk masin-masing proses 


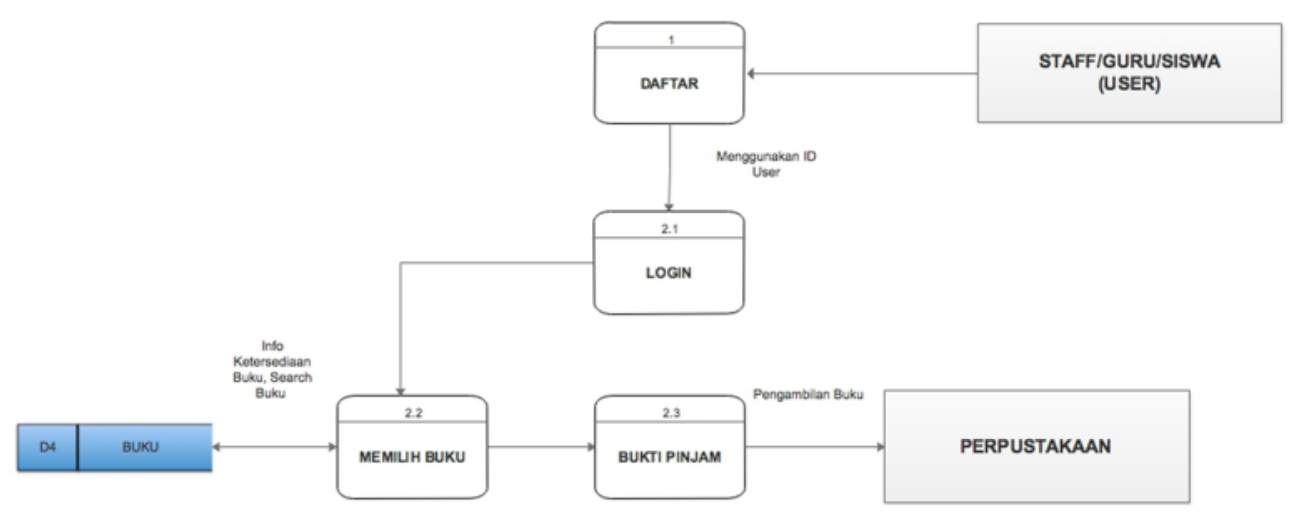

Gambar 4 DFD Level 1 untuk proses Peminjaman

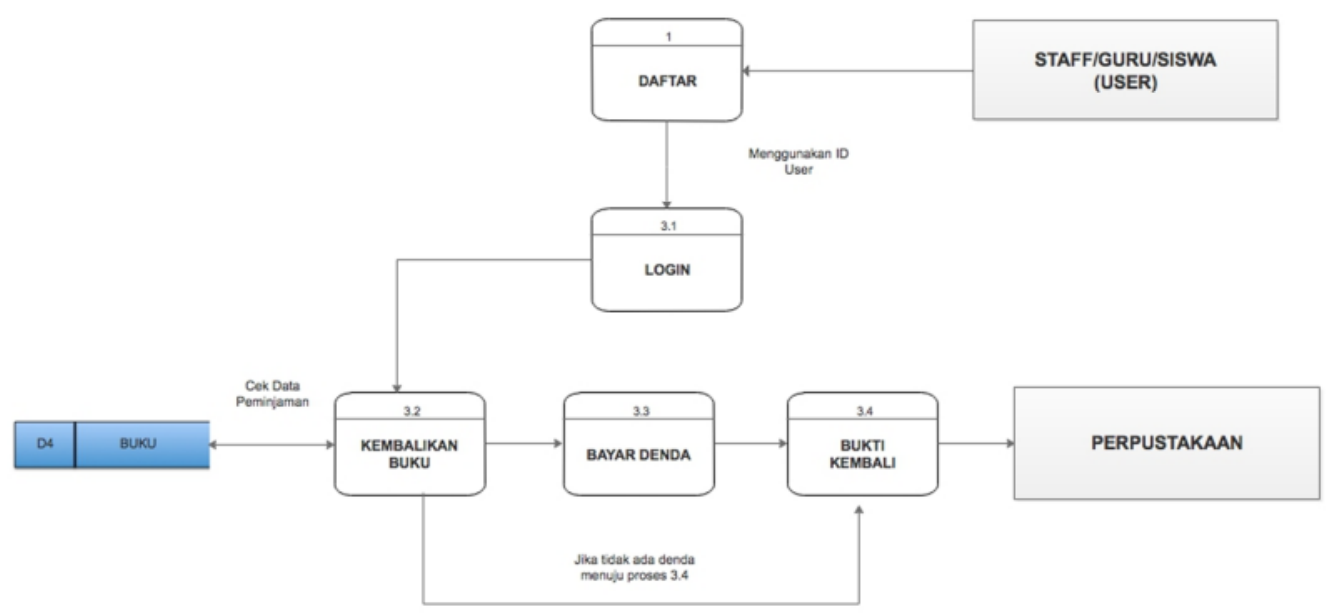

Gambar 5 DFD Level 1 untuk proses Pengembalian

\subsection{Deskripsi Proses}

Secara umum deskripsi proses yang berlangsung dalam sistem ini adalah pertama-tama pengguna akan melakukan pendaftaran dengan mengisikan biodata diri. Setelah admin memberikan autorisasi dan pengguna melakukan verifikasi, maka pengguna dapat menggunakan layanan yang ada pada sistem. Data dari pengguna akan tersimpan pada datastore D1. Kemudian pengguna akan memilih antara layanan untuk perpustakaan ataupun usaha kesehatan sekolah. Pada layanan usaha kesehatan sekolah pengguna hanya akan melihat laporan dari pemeriksaan yang dilakukan pada sistem. Data laporan kesehatan terdapat pada datastore D2. Sedangkan pada layanan perpustakaan pengguna bisa memilih untuk melakukan peminjaman ataupun pengembalian.

Pada peminjaman pengguna dapat mengakses datastore D4 untuk mencari buku yang diinginkan. Lalu melakukan proses peminjaman dan mendapatkan bukti peminjaman yang tersimpan pada datastore D3. Untuk pengembalian pengguna dapat melihat kembali data peminjaman di datastore D3 dan melakukan proses pengembalian buku. 


\section{PERANCANGAN SISTEM}

Perancangan sistem adalah tahapan dari siklus pengembangan sistem yang dapat didefinisikan sebagai tahap pendefinisian kebutuhan-kebutuhan fungsional dan menggambarkan bagaimana suatu sistem dibentuk. Penggambaran dapat berupa sketsa yang terdiri atas perancangan diagram entitas (Entity Relationship Diagram) juga perancangan antarmuka [3].

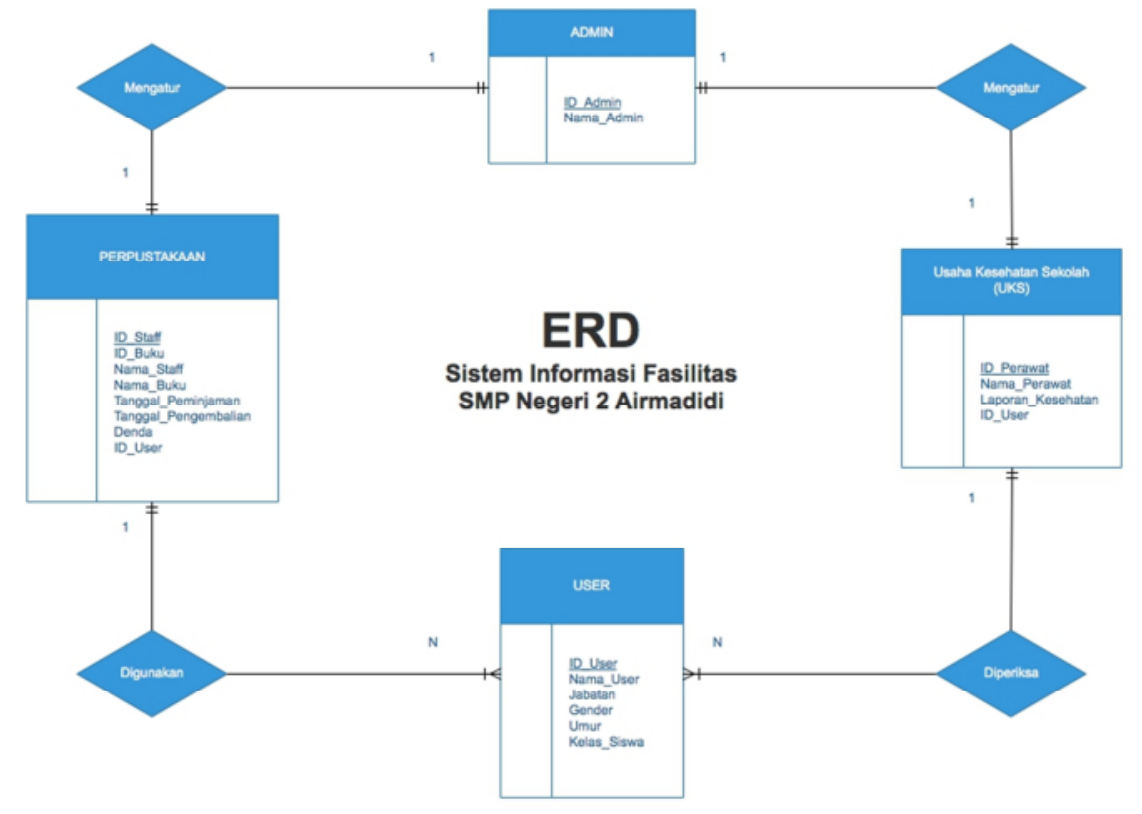

Gambar 6 Entity Relationship Digram dari sistem

Gambar 6 menunjukkan diagram entitas yang telah dibuat dimana terdapat empat entitas dengan masing-masing atribut yang menjelaskan tiap entitas. Setiap entitas memiliki satu atribut unik untuk membedakan satu entitas dengan entitas lainnya.

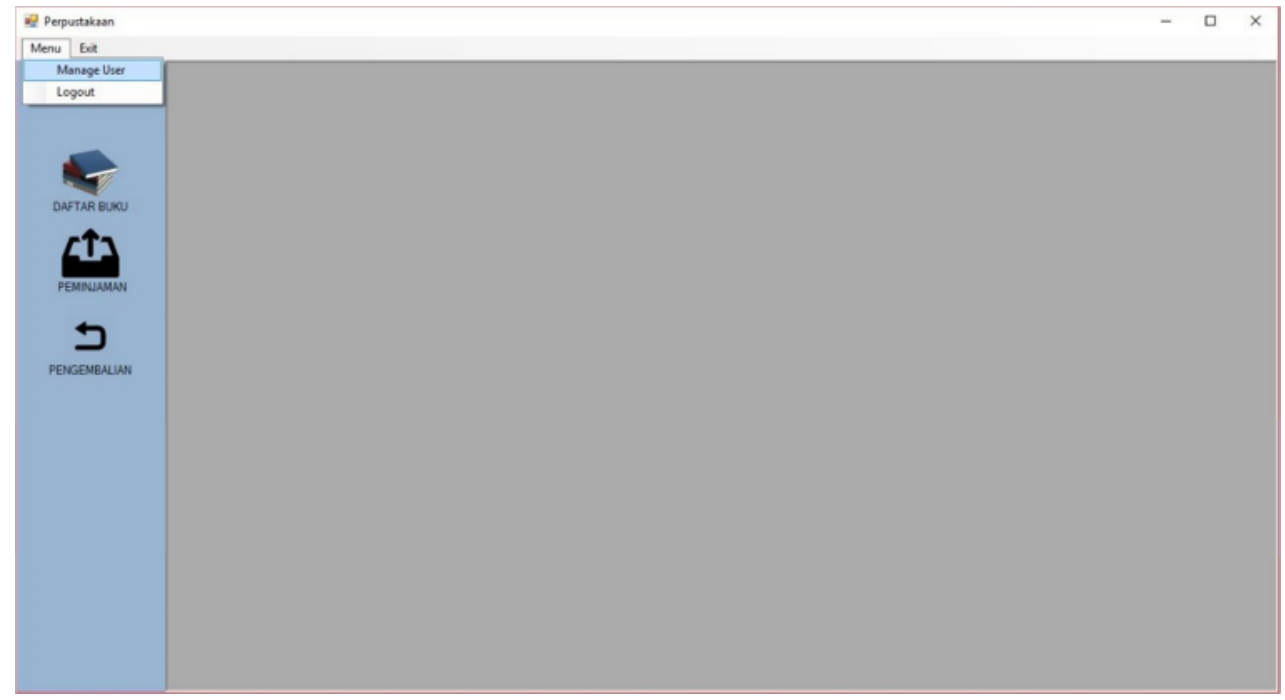

Gambar 7 Rancangan antarmuka untuk menu Perpustakaan

Gambar 7 dan 8 memberikan gambaran mengenai rancangan antarmuka dari sistem yang akan dikembangkan. 


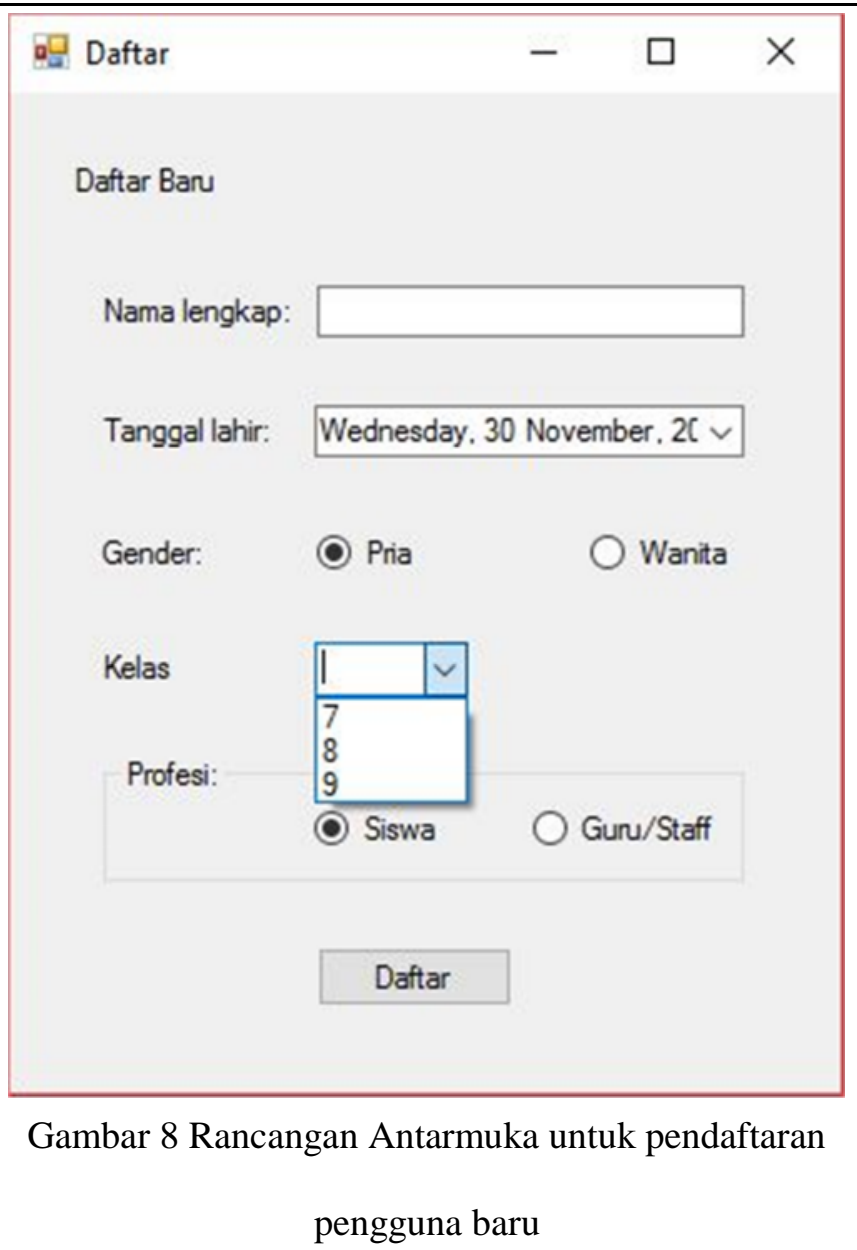

\section{Kesimpulan dan Saran}

Perkembangan teknologi yang begitu pesat dapat diterapkan dalam berbagai bidang. Di saat yang sama, penerapan teknologi melalui pengembangan sistem informasi pada fasilitas sekolah di SMP Negeri 2 Airmadidi ini juga memberikan pengetahuan dini kepada siswa-siswa mengenai penerapan teknologi dalam dunia nyata yang dapat memudahkan dan mendukung aktivitas belajar mengajar. Peneliti menyadari masih terdapat kekurangan dalam penelitian ini dimana dalam proses analisa masih digunakan metode terstruktur yakni berupa diagram alur kerja atau Data Flow Diagram (DFD). Untuk penelitian lebih lanjut dapat dikembangkan sistem dengan analisis menggunakan pendekatan berorientasi objek (Object Oriented Analysis and Design).

\section{Ucapan Terima Kasih}

Penulis mengucapkan terima kasih kepada Fakultas Ilmu Komputer Universitas Klabat dan SMP Negeri 2 Airmadidi yang telah memberi dukungan terhadap penelitian ini.

\section{Daftar Pustaka}

[1] H. Al Fatta, Analisis dan Perancangan Sistem Informasi untuk keunggulan bersaing perusahaan dan organisasi modern: Penerbit Andi, 2007.

[2] K. E. Kendall and J. E. Kendall, "Analisis dan Perancangan sistem," 2018. 
[3] J. W. Satzinger, R. B. Jackson, and S. D. Burd, Systems analysis and design in a changing world: Cengage learning, 2011.

[4] J. A. Hoffer, Modern Systems Analysis and Design, 6/e: Pearson Education India, 2012.

[5] P. T. Ward, "The transformation schema: An extension of the data flow diagram to represent control and timing," IEEE Transactions on Software Engineering, pp. 198-210, 1986.

[6] L. Wang and T. Raz, "Analytic hierarchy process based on data flow diagram," Computers \& industrial engineering, vol. 20, pp. 355-365, 1991. 